\title{
A DURABILITY ANALYSIS OF FORGING TOOLS FOR DIFFERENT OPERATING CONDITIONS WITH APPLICATION OF A DECISION SUPPORT SYSTEM BASED ON ARTIFICIAL NEURAL NETWORKS (ANN)
}

\section{ANALIZA TRWAŁOŚCI NARZĘDZI KUŹNICZYCH DLA RÓŻNYCH WARUNKÓW EKSPLOATACJ Z WYKORZYSTANIEM SYSTEMU WSPOMAGANIA DECYZJ OPARTEGO O SZTUCZNE SIECI NEURONOWE*}

\begin{abstract}
The paper presents the results of research concerning the percentage participation of destructive mechanisms for two typical variants of exploitation of forging tools: lubricated and cooled, and without lubrication. Discussed results come from the developed by the authors the decision support system (SEPEK-2) based on artificial neural network. The knowledge about the durability of forging tools needed for learning artificial neural network was included in the training data set, from comprehensive studies, carried out in industrial conditions. Set of training data set included 450 records of knowledge. The paper presents the process of acquiring knowledge, adopted neural network architecture and parameters developed network. Carried out a global analysis of the results generated by the developed system for the durability of forging tools treated as the maximum number of produced forgings to their destruction (from 0 to 25,000 items), showed that for the lubricated and cooling tools the dominant mechanism is thermo-mechanical fatigue, and do not abrasive wear, which actually dominates in the process of forging tools for uncooled and unlubricated tools. It should be emphasized that the overwhelming majority of studies in this area is attributed that to abrasive wear is dominant, and as shown by the results of research and analysis for the selected representative forging processes, with the use of decision support system based on ANN, the fatigue a thermo-mechanical is dominant in these processes. However, due to the easy measurability and commonly used models wear, based on the model of Archard, it is abrasive wear assigned the largest participation. In fact, for the tool lubricated and cooled tools a thermo-mechanical fatigue intensifies this effect attributed to abrasive wear. While the generally accepted view is correct, in the case of tools unlubricated, as confirmed by the analysis using ANN.
\end{abstract}

Keywords: artificial neural network; decision support system; die forging; durability of forging tools; wear and destructive mechanisms.

\begin{abstract}
W pracy przedstawiono wyniki badań, dotyczace, procentowego udziatu mechanizmów niszczacych dla dwóch typowych wariantów eksploatacji narzędzi kuźniczych: smarowanych i chłodzonych oraz bez smarowania. Prezentowane wyniki pochodza z opracowanego przez autorów systemu wspomagania decyzji (SEPEK-2) działającego w oparciu o sztuczna sieć neuronową. Wiedza o analizowanym zagadnieniu trwałości narzędzi kuźniczych, potrzebna do procesu uczenia sztucznej sieci neuronowej zawarta była w zestawie danych uczacych, pochodzacych z kompleksowych badań, zrealizowanych w warunkach przemystowych. Zestaw danych uczacych obejmowat zbiór 450 rekordów wiedzy. W pracy przestawiono proces pozyskiwania wiedzy, przyjęta architekturę sieci neuronowej oraz parametry opracowanej sieci. Przeprowadzona globalna analiza wyników generowanych przez opracowany system, dla trwałości traktowanej jako zwiększająca się liczba odkuwek (od 0 do 25000 sztuk), wykazała że dla narzędzi smarowanych i chłodzonych dominujacym mechanizmem jest zmęczenie cieplno-mechaniczne, a nie zużycie ścierne, które rzeczywiście dominuje w procesach kucia dla narzędzi niechłodzonych i niesmarowanych. Należy podkreślić, że zdecydowana większość opracowań z tego obszaru przypisuje, że to zużycie ścierne jest dominujące, a jak wykazały wyniki badań i analiz dla wybranych reprezentatywnych procesów kucia, przy wykorzystaniu systemu wspomagania decyzji opartego o SNN, to zmęczenie cieplno-mechaniczne jest dominujace w tych procesach. Jednakże ze względu na łatwa mierzalność oraz popularnie stosowane modele zużycia ściernego, bazujące na modelu Archarda, to właśnie zużyciu ściernemu przypisuję się największy udziat, choć w rzeczywistości dla narzędzi smarowanych i chłodzonych zmęczenie cieplno-mechaniczne wzmaga ów efekt przypisywany zużyciu ściernemu. Natomiast ogólnie przyjęty pogląd jest stuszny, w przypadku narzędzi niesmarowanych. co potwierdzity także analizy przy wykorzystaniu SNN.
\end{abstract}

Slowa kluczowe: sztuczna sieć neuronowa; system wspomagania decyzji; kucie matrycowe; trwałość narzędzi kuźniczych; zużycie i mechanizmy niszczące.

\section{Introduction}

Forging tools used in semi-hot and hot die forging processes characterize in a relatively low durability, which, in turn, significantly affects the quality and cost of the fabrication of forgings. The low durability of forging tools is mostly caused by the extreme conditions of the industrial hot forging processes, resulting from a simultaneous occurrence of many complex phenomena and degradation mechanisms. It is a difficult and unresolved issue, both scientifically and economically. The degradation and wear of forging instrumentation during its performance constitutes a significant part of the production costs $[8,9]$. At present, it is estimated that the costs of tools can constitute up to $8-15 \%$ of the total production costs, and in extreme cases, with small production series, even $30 \%$. In practice, considering the

(*) Tekst artykułu w polskiej wersji językowej dostępny w elektronicznym wydaniu kwartalnika na stronie www.ein.org.pl 
time needed to replace the used instrumentation or in the case of its unexpected degradation, these costs can rise even up to $40 \%$. Also, tool wear significantly lowers the quality of the fabricated forgings. The most common forging defects caused by tool wear are errors in the filling of the die, that is: incomplete forgings, laps, burrs, curvatures, scratches, delaminations, micro- and macro-cracks, etc., which, in turn, affects the functionality of the final product obtained from the forging [11].

In the literature you can find information, that statistically $70 \%$ of the forging dies is withdrawn from production due to the loss dimensions - due to abrasive wear and plastic deformation [16], 25\% - as a consequence of fatigue cracks and only $5 \%$ for other reasons (non-compliance with the technology, construction and material defects, thermal and thermo-chemical treatment defects, etc.) [13]. What is more, the continuous market competition forces the producers of forged goods to constantly lower the costs and produce high quality forgings, and this generates high interest in the problem of tool life improvement [7,12]. More and more often both manufacturers of forging instruments, as well as research centers and research and development use a variety of IT tools and advanced research and develop modern methods allowing both to analyze and to increase the durability of forging tools. Studying the destructive mechanisms and other phenomena accompanying ago and life prediction tools in the forging process is a very difficult and complex issue, and additionally commonly used modes of failure are not described satisfactorily in an analytical way $[1,4,15,19,23]$.

Predicting the life of a forging tool used in a die forging process and pointing to the dominant wear mechanisms and their effect on the 'life time' of the tool are very important, and they still constitute a not fully resolved problem, in respect of both science and economy $[7,11]$. Developing methods which allow for determining the wear (failure) of tools and predicting their life is justified by many factors, such as: continuous perfection of the forging technology, lowering the costs of manufacturing the tools themselves or the cost per unit of the production of one forging, as well as ecological aspects [7, 11, 12]. Modern IT technologies are constantly offering new methods and approaches making it possible to partially replace the costly and timeconsuming material experiments with a virtual experiment. Also, new formalisms of representing knowledge in computer systems are being developed, such as: the graph theory, fuzzy logic, artificial neural networks, or genetic algorithms, thus providing the opportunity to construct expert systems supporting various areas of human activity. Expert systems are widely applied mainly as advisory systems for the tasks of identification, classification, control, simulation and diagnostics. $[2,3,5,14,18,19,21,24,29]$.

The authors made an attempt at elaborating an original decision support system, whose basic task is to predict the life of the forging tools used in hot die forging processes, as well as to identify the basic failure mechanisms. During the many years of research concerning the analysis of the effect of the particular failure mechanisms on the life of forging tools, certain experimental data have been collected. The data are an excellent source of training data for artificial neural networks. The effects of these studies are presented in this article. Thanks to the developed decision support system based on artificial neural networks (ANN) was achieved interesting research results regarding the real participation of major destructive mechanisms for lubricated and cooled tools as well for unlubricated tools.

\section{Expert systems in industrial applications}

Modern IT technologies are constantly offering new methods and approaches making it possible to partially replace the costly and timeconsuming material experiments with a virtual experiment.

An expert systems are widely used mainly as an advisory systems for the tasks of identification, classification, control, simulation, di- agnostics. The broadest range of expert systems applications are in technology, inter alia, to diagnose the state of equipment and failure analysis of experimental data, the design of the control devices, design and technology. The literature often attempts at elaborating expert systems, including ones for the optimization of forging processes. These systems have different aims and take advantage of various formal methods of the system knowledge representation. Katayama et al. developed an expert system to design a cold forging process. Fuzzy logic was used to formulate the principles of the database of this system [14]. Fuzzy logic was also used to develop an expert system for predicting the analysis results with the finite element method when solving the problem of rubber cylinder compression [24]. Gangopadhyay et al. elaborated an expert system for predicting loads and axial stresses during forging [3]. Artificial neural networks have been applied to solve many problems. The application of the finite element method and intelligent system techniques to predict the applied force during the radial forging process was studied in [2]. An artificial neural network was also applied to acquire the relationships between the mechanical properties and the deformation technological parameters of the TC11 titanium alloy, with the use of the data from the isothermal compression test and the conventional tensile test of the forged TC11 titanium alloy at room temperature [18]. In another work [25], the forging and heat treatment experiments of the Ti-6Al-4V alloy were conducted with various experimental parameters, including the forging temperature, deformation degree and heat treatment. On the basis of the obtained experimental data, the optimal model of the hot processing parameters of the Ti-6Al-4V alloy was established with the help of a combination of artificial $n$ neural networks and genetic algorithms.

\subsection{Artifical neural networks}

Artificial neural networks (ANN) are seen as a separate field of knowledge, offering control and decision-making tools, which perform not only the tasks of approximation, classification and pattern recognition, but also prediction, control and association [20]. ANN are used as advanced analytical tools, useful mainly when it is necessary to model phenomena which are highly non-linear in character, multidimensional functional dependences etc. [29]. Their advantage is the ability to determine the dependences between variables, by way of multiple representations of the training case network or on the basis of the similarities among the cases.

A neural network consists of connections of many neurons arranged in layers. The first layer is the input layer, which does not perform any calculations, and its task is to provide the input signal for the consecutive layers. There are intermediate (so called, hidden) layers. The number of hidden layers depends on the degree of complexity of the modelled function. Most of the existing solutions apply one hidden layer. Within one layer, the neurons are not interconnected. The output layer is the layer which provides the result of the network operation for the analyzed output parameters. The signal transmission in the network usually takes place in the direction from the input to the output, without feedback. There are many types and sorts of neural networks, which differ in the structure and principles of operation [27, $28]$. The most popular one is the network architecture connected with the concept of Multi-Layer Perceptron (MLP) [20].

The neural network training methods, broadly discussed in the literature $[20,27,26]$, consist in a cyclic update of the network weights based on the information on the objective function gradient and the minimization direction determined in each step. There are many algorithms of MLP network training, such as: the error back propagation algorithm, the steepest descent algorithm, the variable metric algorithm, the Levenberg-Marquardt algorithm, the Gauss-Newton algorithm (the non-linear least square method) and the coupled gradient algorithm. The most effective methods are thought to be the ones 
based on the Newton algorithm, which are known as the variable metric methods or quasi-Newton methods. They include: the BFGS (Broyden-Fletcher-Goldfarb-Shanno) method, used in the network elaborated by the authors, and the DFP (Davidon-Fletcher-Powell) method.

Appropriately designed neural networks can formulate dependences occurring between the phenomenon parameters during the learning process. The learning process is an iterative one, repeated multiple times, step by step, whose basic objective is optimization of the network parameters, i.e. the weight coefficients. The objective of neural network training is such selection of its topology and parameters which will assure minimization of error when the output value is set.

\section{Methodology section}

The article focuses on the analysis of the results, which achieved from the system, developed by the authors, to analyze the durability of forging tools. To build a system used the comprehensive results of long-term experimental research conducted in industrial conditions, relating to three selected representative hot die forging processes. Analysis of the source data allowed, for knowledge representation in the system (as a formal tool) accept artificial neural networks. The ANN is used as an advanced analysis tools useful mainly in cases when it is necessary of phenomena modeling with highly nonlinear nature multidimensional depending function, as is the case in processes analyzed. Another advantage of neural networks is their ability to independently explore the relationships between variables either by presenting multiple network cases learners. Scheme of work and methodology shown in Figure 1.
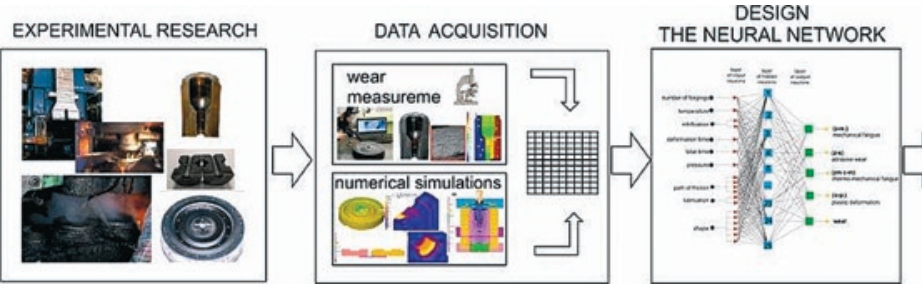

Fig. 1. The flowchart of research methodology

The first version of the system (SEPEK-1), applies fuzzy logic as the form of knowledge representation [5]. This choice was mainly determined by the character of the obtained source data, which are the results of measurements and observations as well as results of computer simulations. They are mainly incomplete data (representing only particular cases for a given number of forgings under given conditions). They are also uncertain as burdened by measurement and observation errors. Fuzzy logic is a formalism which finds its application in the processing of this type of knowledge. The conclusions drawn by the system were verified by experts and recognized as correct and true. The elaborated system, with the use of a fuzzy knowledge base, works with an error at the level of $10 \%$, but the collected data did not fully cover all the analyzed areas. In some cases, the reply generated by the system was that there was no knowledge (rules) based on which a decision could be made.

In the search for forms of knowledge representation which, based on the elaborated experimental data, will make it possible to construct a model characterizing in a lower error and cover all the analyzed areas, Therefore the authors decided to look for other forms of knowledge representation, which on the basis of collected and developed experimental data allow to build a model characterized by even lower error and covering all analyzed areas. Hence it was decided to use artificial neural networks and to develop a new decision support system SEPEK-2.

\subsection{Description of experimental data used in model con- struction}

To build a knowledge module, three types of industrial forging processes were selected, so that these processes would occur under a variety of conditions that determine the durability of forging tools. The authors' experience suggests that such differentiation of forging conditions (due to temperature, pressure, path friction, thermo-chemical, tribological conditions, etc.) can be obtained by way of selecting:

I Hot forging of a front wheel in open dies.

II Precision forging of a CVJB (constant velocity joint) housing in closed die.

III Forging of a fastener in a closed die without lubrication and cooling tools.

I Hot forging of a front wheel in open dies - die inserts, heated to $250^{\circ} \mathrm{C}$, and cooled and nitrided only in operation 2 and 3, initial billet heated inductively to $1150^{\circ} \mathrm{C}$. A wheel forging (Fig 2c),
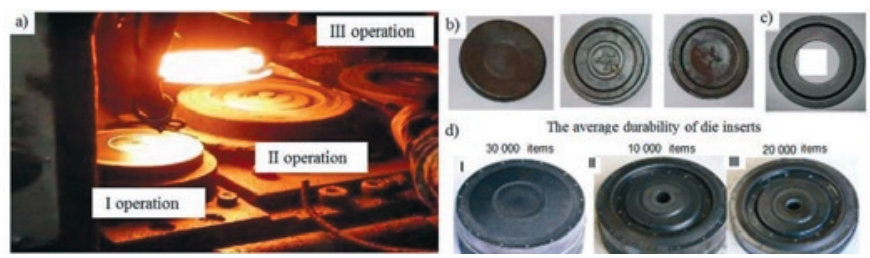

Fig. 2. The view of forging process: a) tools mounted on a press, b) forgings after consecutive operations, c) a ready front wheel forging (after punching and trimming, before toothing), d) lower die inserts for I, II, III operation

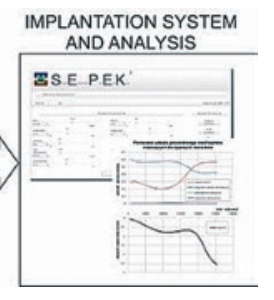

after toothing, is used in the gear box as the front wheel of the reverse gear in motorcars. The analyzed process is realized on a crank press of the nominal force of $25 \mathrm{MN}$, in three forging operations (Fig. 2): operation I - upsetting, operation II - preliminary die forging and operation III finishing forging (Fig 2b). The forged material is the $\mathrm{C} 45$ steel, in the shape of a cylinder. The data obtained from a detailed analysis of the lower die inserts from the first, second and third forging operation were entered into the system database (Fig 2d).

II Precision forging of a CVJB (constant velocity joint body) housing in closed dies - tools not preheated, lubricated and cooled, initial billet inductively heated to $920^{\circ} \mathrm{C}$. The industrial forging of a CV universal joint housing in the GKN Driveline Forge consists of four hot forging operations and one cold forging operation (Fig. $3)$. The forging 's material is the $\mathrm{XC} 45$ steel. The dies and punches are made of the Unimax steel for hot working tools (1.2367). After the heat treatment tool have a hardness of 48-52 HRC. The tools are not nitrided and not heated before the process, are pre-charged
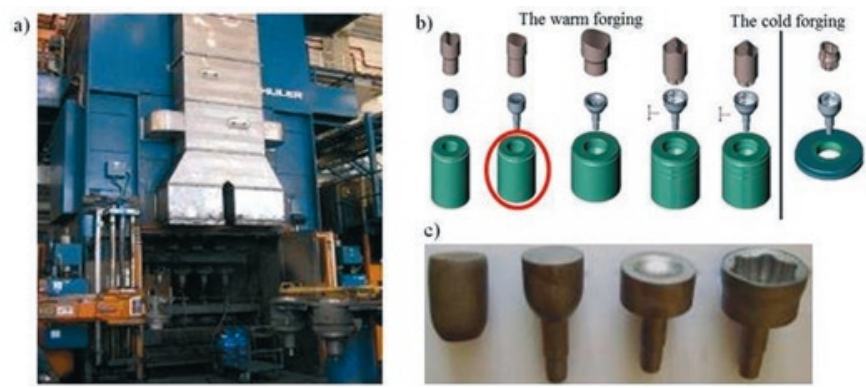

Fig. 3. The precision forging process: a) crank press, b) scheme of individual operations (V operation - marking), c) forgings after successive operations 
to a special welding agent (Aerodag CERAMISHIELD) in order to reduce the risk of rupture in a thermal shock caused by contact with the hot preform at the beginning of process. In addition, the punch of the fourth operation is heated in a special device and 2-times immersed in a mixture of graphite with water (on the press is mounted, unheated). Tools after forging a few pieces forgings reach operating temperature $\left(250-300^{\circ} \mathrm{C}\right)$.

III Forging of a fastener (type of Putanker 1,3T) used to move concrete slabs, in a closed die without lubrication and cooling tools, billet is heated inductively (locally, Fig $4 \mathrm{~b}$ ) to $1000{ }^{\circ} \mathrm{C}$, in three operations on a PMS 160B eccentric press (Fig. 4a) with the use of a TR device (Fig. 4c). Figure 4d shows the forgings after each operation. Figure $4 \mathrm{e}$ shows the tools used in the first, second (Fig. 4f) and third (Fig. 4g) forging operation.
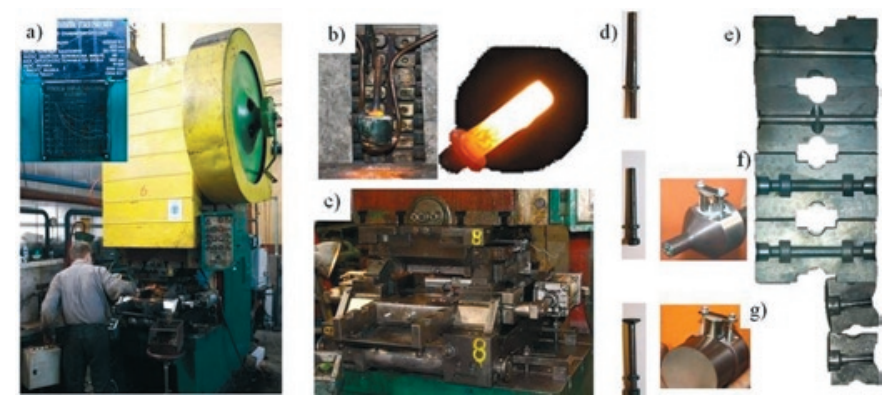

Fig. 4. The view of: a) PMS $160 B$ eccentric press, b) heater with a locally heated preform for the second operation, c) TR device, d) forgings after successive operations, e) dies for the first operation, f) tools for the second operation (punch with AE sensor), g) tools for the third operation (punch with AE sensor)

The punches and the die inserts are made of steel WCL and ORVAR SUPREME (WCLV), which the hardness after heat treatment was 58 HRC. In addition, the second and third operations are used punches (in the first operation-upsetting is done by two dies, without the punch). The tools are not nitrided and pre-heated. Average life of the die inserts are: 12,000 for the first operation, for the second operation about 8000 forgings, and for the third operation about 10,000 forgings. The data obtained from a detailed analysis of only second die was entered into the system database.

After the selection of representative processes, their most important parameters were determined, such as: charge and tool temperature, forming force, velocities, tribological conditions, preform and final product geometry as well as tool shape. These parameters were determined based on the operation sheets. The remaining significant parameters, hard or impossible to determine (pressures, path of friction, temperatures in contact etc.) were determined by means of numerical modelling verified by a measuring and monitoring system [10]. The geometrical defect (wear) of the die impressions was determined based on a comparison of the superimposed laser scan images of the new and the worn tools (after a specific number of forgings) [6].

After the analysis of the selected die forging process, three groups of parameters were specified, which had a significant effect on the tool wear, that is:
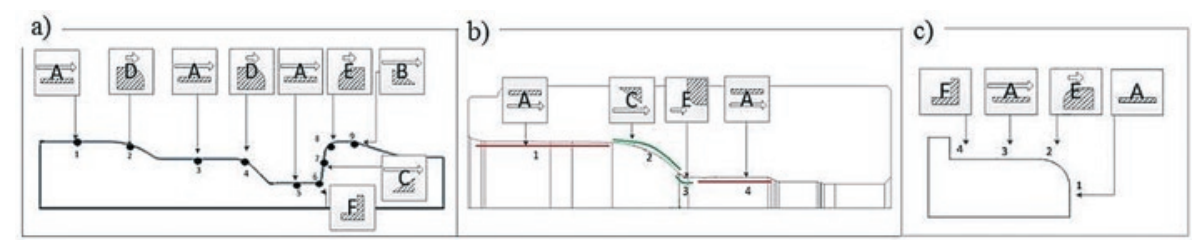

Fig. 5. Cross section with schematic division into areas and elementary shapes for: a) die insert used in forging front wheel, b) die used in precision forging of CVJB housing, c) a formed part of die for the first operation
- parameters of the forging process (number of forgings, number of operations, and for each operation, also: charge temperature; pressures; lubrication; cooling intensity etc.),

- parameters characterizing the tool (die) - Fig. 5a shows an exemplary schematic of the division of the die insert's cross section for the second operation of hot forging a front wheel in a closed die, while Fig. $5 \mathrm{~b}$ presents the precision forging of a constant-velocity universal joint housing and Fig. 5c shows scheme of cross section of part die to forging fasteners. All forging tools are divided into elementary areas (1-9), described with symbols representing elementary shapes (A-F), distinguishable in any die.

- parameters characterizing the charge material.

The assumptions and system tasks (prediction of the life of the forging tools used in the hot die forging process, as well as identification of the critical points and wear mechanisms) made it possible to define the parameters providing the information on the tool wear, which are:

- failure mechanism (4 wear mechanisms were considered: thermo-mechanical fatigue, mechanical fatigue, abrasive wear and plastic strain) as well as the mechanism's participation in the failure of the given area;

- geometrical defect - loss of material (wear [mm]).

The detailed information on the process of obtaining primary data for the specified parameters describing the selected process was thoroughly discussed in [5]. Table 1 shows a fragment of the elaborated set of data.

The global table contains 450 knowledge vectors. The number of forgings was analyzed in the range of 0-25000.

\section{The neural network model}

The process of constructing a neural network model consists of the following stages: determination of independent and dependent variables; selection of neural network type and determination of its structure; neural network training and evaluation of network model.

\subsection{Determination of independent and dependent vari- ables}

A neural network's task is to show the effect of the particular factors on the wear of the die during the die forging process. It calculates the participation of the particular mechanisms, i.e. thermo-mechan-

Table 2. Dependent variables

\begin{tabular}{||c|c|c|}
\hline \hline L.P. & OUTPUT variables & Scope \\
\hline 1 & thermo-mechanical fatigue & $0-1$ \\
\hline 2 & abrasive wear & $0-1$ \\
\hline 3 & plastic strain & $0-1$ \\
\hline 4 & mechanical fatigue & $0-1$ \\
\hline 5 & wear & $-3 \div 0,05$ \\
\hline
\end{tabular}

ical fatigue, abrasive fatigue, plastic strain and mechanical wear, in the failure process. It also calculates the wear of the tool itself in the specified area.

Table 2 shows the dependent variables - the process parameters which are determined as the network output. As the independent variables, having an effect on the presented output variables, the following were selected from the global set of data: number of forgings, temperature, hardness, deformation time, total time, pressure, 
Table 1. Fragment of table with data

\begin{tabular}{|c|c|c|c|c|c|c|c|c|c|c|c|c|c|}
\hline $\begin{array}{l}\text { number of } \\
\text { forgings }\end{array}$ & shape & $\begin{array}{l}\text { temperature } \\
\text { [C] }\end{array}$ & $\begin{array}{c}\text { nitrification } \\
\text { [yes/no] }\end{array}$ & $\begin{array}{c}\text { deformation time } \\
\text { [s] }\end{array}$ & total time [s] & $\begin{array}{l}\text { preasure } \\
\text { [MPa] }\end{array}$ & $\begin{array}{l}\text { path of } \\
\text { friction }\end{array}$ & $\begin{array}{c}\text { lubrication } \\
{[1 / 0]}\end{array}$ & $z-\mathrm{cm}$ & $z-s$ & o-p & $z-m$ & wear $[\mathrm{mm}]$ \\
\hline 550 & A & 1200 & no & 0,162 & 1,663 & 160 & średnia & 0 & 0,50 & 0,50 & 0,00 & 0,00 & $-0,26$ \\
\hline 550 & $A$ & 1100 & no & 0,162 & 1,663 & 160 & średnia & 0 & 0,00 & 1,00 & 0,00 & 0,00 & $-0,2$ \\
\hline$\ldots$ & .. & &.. &.. &.. &.. & .. & .. &.. &.. &... & \begin{tabular}{|l|}
.. \\
\end{tabular} &.. \\
\hline 1850 & $E$ & 1200 & yes & 0,038 & 0,558 & 500 & very high & 1 & 0,33 & 0,33 & 0,33 & 0,00 & $-0,4$ \\
\hline 1850 & A & 1200 & yes & 0,058 & 1,068 & 960 & very high & 1 & 0,60 & 0,20 & 0,20 & 0,00 & $-0,2$ \\
\hline 1900 & $A$ & 1200 & no & 0,165 & 0,165 & 140 & very high & 0 & 0,30 & 0,30 & 0,40 & 0,00 & $-0,26$ \\
\hline 1900 & $A$ & 1100 & no & 0,165 & 0,165 & 140 & very high & 0 & 0,30 & 0,40 & 0,30 & 0,00 & $-0,2$ \\
\hline$\ldots$ & .. &.. &.. & .. & .. &.. & ... &.. &.. &.. &.. & ... &.. \\
\hline 2200 & $E$ & 1100 & no & 0,038 & 2,476 & 384 & very high & 0 & 0,00 & 0,50 & 0,00 & 0,50 & $-0,1$ \\
\hline 2200 & E & 1100 & no & 0,038 & 2,476 & 384 & very high & 0 & 0,00 & 0,50 & 0,00 & 0,50 & $-0,07$ \\
\hline$\ldots$ &.. &.. &.. &.. &.. &.. & ... &.. &.. &.. & \begin{tabular}{|l|}
.. \\
\end{tabular} & ... &.. \\
\hline 2500 & $A$ & 1150 & yes & 0,088 & 0,088 & 1074 & very high & 1 & 0,35 & 0,35 & 0,30 & 0,00 & $-0,568$ \\
\hline 2500 & $E$ & 1150 & yes & 0,087 & 0,087 & 1300 & very high & 1 & 0,33 & 0,33 & 0,33 & 0,00 & $-0,189$ \\
\hline$\ldots$ &.. &.. &.. & .. & .. &.. & ... & .. &.. &.. & \begin{tabular}{|l|}
.. \\
\end{tabular} & \begin{tabular}{|l|}
.. \\
\end{tabular} & .. \\
\hline 4000 & $E$ & 1100 & no & 0,111 & 0,631 & 480 & very high & 1 & 0,25 & 0,25 & 0,30 & 0,20 & $-0,6$ \\
\hline 4000 & C & 1100 & no & 0,117 & 0,717 & 560 & very high & 1 & 0,33 & 0,33 & 0,33 & 0,00 & $-0,3$ \\
\hline$\ldots$ &.. &.. &.. & .. & .. &.. & ... &.. &.. &.. & \begin{tabular}{|l|}
.. \\
\end{tabular} & \begin{tabular}{|l|}
.. \\
\end{tabular} &.. \\
\hline 4300 & $E$ & 1200 & yes & 0,038 & 0,558 & 500 & very high & 1 & 0,40 & 0,40 & 0,20 & 0,00 & $-1,6$ \\
\hline 4300 & A & 1200 & yes & 0,058 & 1,068 & 960 & very high & 1 & 0,40 & 0,30 & 0,30 & 0,00 & $-1,5$ \\
\hline$\ldots$ & .. &.. &.. &.. &.. &.. &.. & ... &.. &.. & ... & ... &.. \\
\hline 6000 & A & 1150 & yes & 0,088 & 0,088 & 1074 & very high & 1 & 0,35 & 0,35 & 0,30 & 0,00 & $-0,786$ \\
\hline 6000 & A & 1150 & yes & 0,072 & 0,072 & 620 & very high & 1 & 0,70 & 0,10 & 0,20 & 0,00 & $-0,065$ \\
\hline$\ldots$ &.. &.. &.. &.. &.. &.. & ... &.. &.. &.. & \begin{tabular}{|l|}
.. \\
\end{tabular} & ... & .. \\
\hline 6500 & $A$ & 1100 & no & 0,021 & 1,134 & 320 & very high & 0 & 0,50 & 0,50 & 0,00 & 0,00 & $-0,19$ \\
\hline$\ldots$ & .. &.. &.. &.. &.. &.. & .. & .. &.. &.. &... & \begin{tabular}{|l|}
.. \\
\end{tabular} &.. \\
\hline 6900 & $E$ & 1200 & yes & 0,038 & 0,558 & 500 & very high & 1 & 0,40 & 0,40 & 0,20 & 0,00 & $-2,1$ \\
\hline$\ldots$ &.. & ... &.. & .. &.. &.. & .. &.. &.. &.. & \begin{tabular}{|l|}
.. \\
\end{tabular} & \begin{tabular}{|l|}
.. \\
\end{tabular} & .. \\
\hline 7044 & C & 920 & no & 0,117 & 0,717 & 560 & very high & 1 & 0,80 & 0,20 & 0,00 & 0,00 & $-0,01$ \\
\hline 7044 & A & 920 & no & 0,097 & 0,717 & 650 & very high & 1 & 0,85 & 0,10 & 0,00 & 0,05 & 0 \\
\hline 8000 & E & 1100 & no & 0,111 & 0,631 & 480 & very high & 1 & 0,25 & 0,25 & 0,30 & 0,20 & $-1,5$ \\
\hline$\ldots$ & .. &.. & .. &.. &.. &.. & .. & .. &.. &.. & ... &.. &.. \\
\hline 9000 & A & 1200 & no & 0,162 & 1,663 & 160 & very high & 0 & 0,30 & 0,30 & 0,40 & 0,00 & $-2,6$ \\
\hline 9500 & $E$ & 1200 & yes & 0,038 & 0,558 & 500 & very high & 1 & 0,33 & 0,33 & 0,33 & 0,00 & $-2,7$ \\
\hline$\ldots$ &.. & 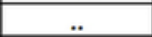 &.. &.. &.. &.. & .. &.. &.. &.. &.. &.. &.. \\
\hline 12000 & C & 1100 & no & 0,117 & 0,717 & 560 & very high & 1 & 0,33 & 0,33 & 0,33 & 0,00 & $-2,4$ \\
\hline 12000 & $E$ & 1100 & no & 0,111 & 0,631 & 480 & very high & 1 & 0,25 & 0,25 & 0,30 & 0,20 & $-2,4$ \\
\hline$\ldots$ &.. & .. & ... &.. &.. &.. & .. &.. &.. &.. & \begin{tabular}{|l|}
.. \\
\end{tabular} & ... &.. \\
\hline 12750 & D & 1150 & yes & 0,087 & 0,087 & 941 & very high & 1 & 0,45 & 0,45 & 0,10 & 0,00 & $-1,285$ \\
\hline 12750 & $A$ & 1150 & yes & 0,072 & 0,072 & 620 & very high & 1 & 0,80 & 0,10 & 0,10 & 0,00 & $-0,161$ \\
\hline 12750 & D & 1150 & yes & 0,063 & 0,063 & 542 & very high & 1 & 0,90 & 0,05 & 0,05 & 0,00 & $-0,032$ \\
\hline$\ldots$ &.. &.. &.. &.. &.. &.. & .. & .. &.. &.. & ... &.. &.. \\
\hline 15500 & A & 1200 & no & 0,162 & 1,663 & 160 & very high & 0 & 0,30 & 0,30 & 0,40 & 0,00 & $-2,6$ \\
\hline 15500 & A & 1100 & no & 0,162 & 1,663 & 160 & very high & 0 & 0,30 & 0,40 & 0,30 & 0,00 & $-2,1$ \\
\hline 16000 & A & 1100 & yes & 0,084 & 0,604 & 210 & very high & 1 & 0,33 & 0,33 & 0,33 & 0,00 & $-0,8$ \\
\hline & & & & & & & & & & & & & \\
\hline 17054 & $A$ & 920 & no & 0,097 & 0,717 & 650 & very high & 1 & 0,60 & 0,25 & 0,00 & 0,15 & $-0,05$ \\
\hline 17054 & c & 920 & no & 0,117 & 0,717 & 560 & very high & 1 & 0,60 & 0,25 & 0,00 & 0,15 & $-0,04$ \\
\hline & & & & & & & & & & & & & \\
\hline 22320 & A & 920 & no & 0,097 & 0,717 & 650 & very high & 1 & 0,70 & 0,15 & 0,00 & 0,15 & $-0,04$ \\
\hline 22320 & A & 920 & no & 0,084 & 0,604 & 210 & very high & 1 & 0,65 & 0,15 & 0,00 & 0,20 & $-0,01$ \\
\hline & & & & & & & & & & & & & \\
\hline 25000 & B & 1100 & yes & 0,005 & 1,444 & 30 & very high & 1 & 1,00 & 0,00 & 0,00 & 0,00 & $-0,7$ \\
\hline 25000 & E & 1200 & yes & 0,034 & 1,444 & 800 & very high & 1 & 0,40 & 0,30 & 0,30 & 0,00 & $-0,22$ \\
\hline 25000 & $\mathrm{E}$ & 1100 & yes & 0,034 & 1,444 & 800 & very high & 1 & 0,80 & 0,20 & 0,00 & 0,00 & $-0,17$ \\
\hline 25000 & D & 1200 & yes & 0,018 & 1,444 & 600 & very high & 1 & 0,70 & 0,20 & 0,10 & 0,00 & $-0,13$ \\
\hline
\end{tabular}

path of friction, lubrication and shape. Table 3 shows the selected independent variables (neural network inputs).

\subsection{Neural network structure and parameters}

The set of data describing the modelled phenomenon (450 knowledge vectors), was divided into the training set (70\%), the validation set $(15 \%)$ and the test set $(15 \%)$. At the network training stage, the training set is applied. The validation set is used to control the course of training by way of verifying how well the neurons are trained. In practice, the training included two phases: selection of weights for the training set and weight testing on samples from the validation set. The modification of the weight values continued until approximation error minimization was achieved or the error in the validation set began to grow.

For the determination of the detailed, as well as optimal, network architecture, the STATISTICA program and its module Automatic Neural Networks were used. Tests were performed on a few tens of architectures with different numbers of hidden neurons and different activation functions in the hidden and the output layer (linear, sigmoidal (logistic), tangensoidal and exponential). From among all the networks generated by the program, the one characterizing in the low- 
Table 3. Idependent variables

\begin{tabular}{|c|c|c||}
\hline L.P. & INPUT variables & Scope \\
\hline 1 & number of forgings & $0-25000$ \\
\hline 2 & temperature $\left[{ }^{\circ} \mathrm{C}\right]$ & $900-1200$ \\
\hline 3 & nitrification & yes/no \\
\hline 4 & deformation time $[\mathrm{s}]$ & $0-0,185$ \\
\hline 5 & total time $[\mathrm{s}]$ & $0-2,5$ \\
\hline 6 & pressure $[\mathrm{MPa}]$ & $0-1300$ \\
\hline 7 & path of friction & low, medium, high, very high \\
\hline 8 & lubrication & yes $/$ no \\
\hline 9 & shape & A, B, C, D, E, F \\
\hline
\end{tabular}

est validation error (at the level of $12 \%$ ) was ultimately selected. An additional measure of the model quality was the Pearson linear correlation coefficient $(R)$, calculated in the particular set types (training, validation and test), for the network and the set data reply. The correlation coefficient for the training set reached the value of 0,937 , for the validation set $-0,828$ and for the test set - 0,842 . The assumed error function is the sum of squared deviations (SOS) between the set value and network output calculated for each set. The error value for the training set is at the level of $3 \%$, for the validation set $-12 \%$, and for the test set - 9\%. Considering the problem's degree of complication, the number of input data and the assumed outputs, it can be stated that the network parameters are at a sufficient level. Hyperbolic tangent (Tanah) was assumed as the activation function in the hidden

Table 4. Parameters of MLP 19-25-5 neural network

\begin{tabular}{||c|c||}
\hline Name of network & MLP 19-25-5 \\
\hline Error (training) & 0,039309 \\
\hline Error (validation) & 0,127667 \\
\hline Error (testing) & 0,090174 \\
\hline Quality (training) & 0,937455 \\
\hline Quality (validation) & 0,828000 \\
\hline Quality (testing) & 0,842213 \\
\hline Training algorithm & BFGS 56 \\
\hline Error function & SOS \\
\hline Activation (hidden) & Tanh \\
\hline Activation (output) & Logistic \\
\hline
\end{tabular}

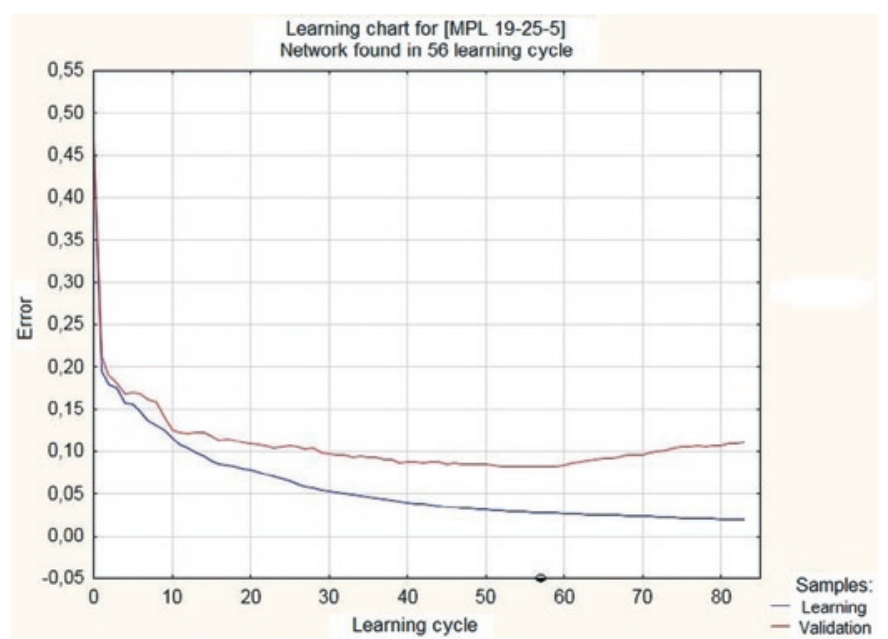

Fig. 6. Changes in errors (training and validation) depending on epoch number for MLP 19-25-5 network

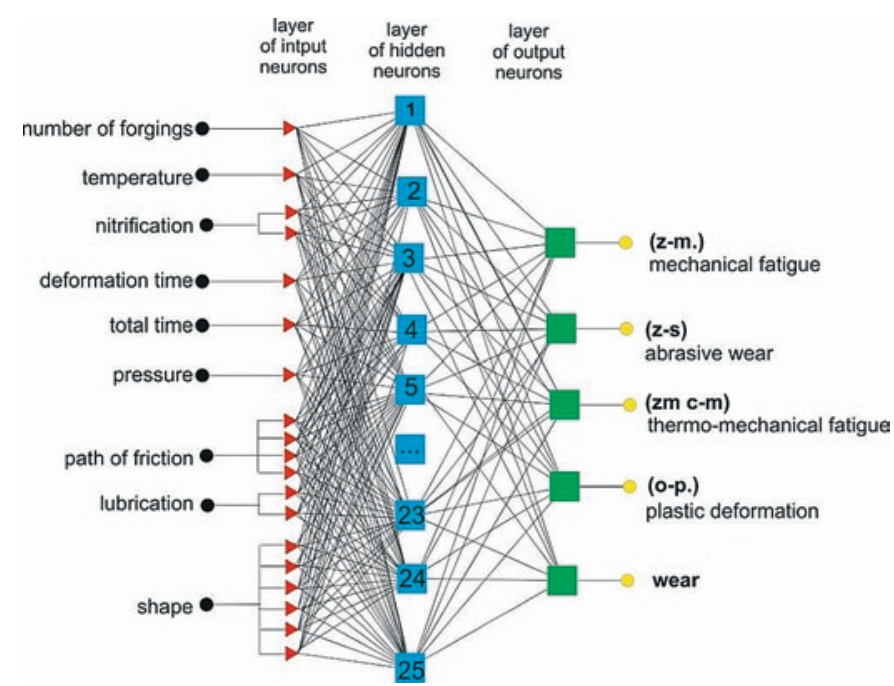

Fig. 7. Diagram of the elaborated MLP 19-25-5 network

neuron layer, and the logistic (sigmoidal) activation function was assumed for the layer of output neurons. Table 4 shows the basic parameters of the elaborated network.

In the case of the selected MLP 19-25-5 network, the assumed minimal approximation error was not achieved; the training process was terminated in 56 epoch, when the validation error started to grow. In this network, the BFGS (Broyden-Fletcher-Goldfarb-Shanno) method was used for training. Fig.6 shows the process of change in the error rate (training and validation) during training.

A simplified structure diagram of the selected network is presented in Fig. 7. The network is of the MLP type, consisting of one input layer ( 9 input variables/19 neurons), one hidden layer ( 25 neurons) and one output layer (5 neurons).

\subsection{Error analysis}

Table shows the basic quality parameters for the elaborated network. The given errors (training, validation, test) concern the total network error calculated as the mean value of the remainder squares for all five output variables.

A detailed analysis of the errors for the MLP19-25-5 network, for the particular output variables, i.e. wear (wear) thermo-mechanical fatigue (z-cm), abrasive wear (z-s), plastic strain (o-p), mechanical fatigue (z-m), separated according to the particular sets: training, validation, test, are compiled in Tables 5-9. The tables contain the following characteristics: remainder squares mean value, mean absolute error, correlation coefficient.

In the analysis of Tables 5-9, we can notice that the elaborated network provides the best results for the mechanical fatigue output variable (z-m). The correlation coefficient for the test set is at the level of 0,99 , which gives a very high linear approximation, and the mean absolute error equals 0,01 . These results are presented in Table 6 . The mean absolute error at the level of 0,04 , for the test set, is exhibited by the plastic strain output variable (o-p), presented in Table 7, where the correlation coefficient for the test set equals 0,8 . The lowest approximation and the highest error can be expected for the thermo-

Table 5. Summary of the network fit level for the observed variable wear

\begin{tabular}{|c|c|c|c|}
\hline wear & $\begin{array}{c}\text { Remainder } \\
\text { squares mean } \\
\text { value }\end{array}$ & $\begin{array}{c}\text { Mean absolute } \\
\text { error }\end{array}$ & $\begin{array}{c}\text { Correlation } \\
\text { coefficient }\end{array}$ \\
\hline Training & 0,0306 & 0,1175 & 0,9577 \\
\hline Validation & 0,1161 & 0,1833 & 0,8147 \\
\hline Testing & 0,0573 & 0,1579 & 0,9200 \\
\hline
\end{tabular}


Table 6. Summary of the network fit level for the observed variable $z-m$

\begin{tabular}{|c|c|c|c||}
\hline $\mathbf{z}-\mathbf{m}$ & $\begin{array}{c}\text { Remainder } \\
\text { squares mean } \\
\text { value }\end{array}$ & $\begin{array}{c}\text { Mean absolute } \\
\text { error }\end{array}$ & $\begin{array}{c}\text { Correlation } \\
\text { coefficient }\end{array}$ \\
\hline Training & 0,0044 & 0,0196 & 0,9664 \\
\hline Validation & 0,0039 & 0,0179 & 0,9759 \\
\hline Testing & 0,0009 & 0,0114 & 0,9954 \\
\hline
\end{tabular}

Table 7. Summary of the network fit level for the observed variable o-p

\begin{tabular}{|c|c|c|c||}
\hline o-p & $\begin{array}{c}\text { Remainder } \\
\text { squares mean } \\
\text { value }\end{array}$ & $\begin{array}{c}\text { Mean absolute } \\
\text { error }\end{array}$ & $\begin{array}{c}\text { Correlation } \\
\text { coefficient }\end{array}$ \\
\hline Training & 0,0018 & 0,0221 & 0,9425 \\
\hline Validation & 0,0043 & 0,0366 & 0,8992 \\
\hline Testing & 0,0061 & 0,0490 & 0,8077 \\
\hline
\end{tabular}

Table 8. Summary of the network fit level for the observed variable $\mathrm{z}-\mathrm{S}$

\begin{tabular}{|c|c|c|c||}
\hline z-s & $\begin{array}{c}\text { Remainder } \\
\text { squares mean } \\
\text { value }\end{array}$ & $\begin{array}{c}\text { Mean absolute } \\
\text { error }\end{array}$ & $\begin{array}{c}\text { Correlation } \\
\text { coefficient }\end{array}$ \\
\hline Training & 0,0114 & 0,0659 & 0,9263 \\
\hline Validation & 0,0359 & 0,1051 & 0,7711 \\
\hline Testing & 0,0356 & 0,1122 & 0,7656 \\
\hline
\end{tabular}

mechanical fatigue output variable $(\mathrm{z}-\mathrm{cm})$, for which the correlation coefficient for the test set is at the level of 0,72 , and the mean absolute error equals 0,17 (table 9).
Table 9. Summary of the network fit level for the observed variable $\mathrm{z}-\mathrm{cm}$

\begin{tabular}{|c|c|c|c||}
\hline z-cm & $\begin{array}{c}\text { Remainder } \\
\text { squares mean } \\
\text { value }\end{array}$ & $\begin{array}{c}\text { Mean absolute } \\
\text { error }\end{array}$ & $\begin{array}{c}\text { Correlation } \\
\text { coefficient }\end{array}$ \\
\hline Training & 0,0303 & 0,1064 & 0,8943 \\
\hline Validation & 0,0949 & 0,1772 & 0,6790 \\
\hline Testing & 0,0802 & 0,1722 & 0,7222 \\
\hline
\end{tabular}

Conducted by the authors of the study in the scope of tool life (material and others $[11,12]$ ), concerning the input variables and their sequence, are correct and the obtained hierarchy of importance is mostly determined by the amount of data and its type. Only the case of the pressure variable, for the elaborated network, is somewhat thought-provoking, as in the case of abrasive wear, described by means of the Archard model, the volume of wear is proportional to i.a. pressure. On the other hand, the Archard model proves effective mainly for non-lubricable contacts. What is more, as it was pointed out earlier, the input variables are generally not independent, and so, even experienced researchers are faced with doubts when separately analyzing some of the results.

\subsection{Modeling results analysis}

The analysis of the results obtained in the inference process, with the use of a virtual experiment, as compared with the results obtained empirically, shows an error at the level of $0-10 \%$. Considering the fact that, in the actual industrial processes, such differences can assume even higher values for the particular tools, and the determination of the dominant mechanism is not always possible, even when it is performed by an experienced operator, the proposed inference model should be treated as sufficient for the analysis of the described process. Exemplary inference results obtained with the use of the elabo-

Table 10. Inference results for selected input scenario

\begin{tabular}{|c|c|c|c|c|c|c|}
\hline 1 & 2 & 3 & 4 & 5 & 6 & 7 \\
\hline \multirow{9}{*}{$\begin{array}{l}\text { 定 } \\
\text { 足 }\end{array}$} & number of forgings & 550 & 1850 & 1850 & 4000 & 4300 \\
\hline & temperature & 950 & 950 & 1200 & 1100 & 950 \\
\hline & deformation time & 0,183 & 0,048 & 0,048 & 0,083 & 0,027 \\
\hline & total time & 1,684 & 1,068 & 1,068 & 0,603 & 1,444 \\
\hline & pressure & 168 & 640 & 640 & 210 & 400 \\
\hline & lubrication & 0 & 1 & 1 & 1 & 1 \\
\hline & shape & A & $\mathrm{D}$ & $\mathrm{D}$ & A & $\mathrm{E}$ \\
\hline & nitrification & no & yes & yes & no & yes \\
\hline & path of friction & low & low & low & high & medium \\
\hline \multirow{5}{*}{ 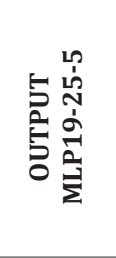 } & wear & 0,0493 & 0,0497 & 0,0342 & $-0,0182$ & $-0,105$ \\
\hline & $\mathrm{z}-\mathrm{cm}$ & 0,000 & 0,877 & 0,912 & 0,403 & 0,149 \\
\hline & z-s & 0,000 & 0,113 & 0,028 & 0,295 & 0,836 \\
\hline & o-p & 0,000 & 0,000 & 0,059 & 0,300 & 0,013 \\
\hline & z-m & 0,000 & 0,010 & 0,001 & 0,000 & 0,000 \\
\hline \multirow{5}{*}{ 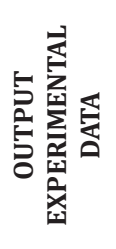 } & wear & 0,000 & 0,000 & $-0,040$ & $-0,020$ & $-0,250$ \\
\hline & $\mathrm{z}-\mathbf{c m}$ & 0,000 & 1,000 & 1,000 & 0,333 & 0,000 \\
\hline & z-s & 0,000 & 0,000 & 0,000 & 0,333 & 1,000 \\
\hline & o-p & 0,000 & 0,000 & 0,000 & 0,333 & 0,000 \\
\hline & z-m & 0,000 & 0,000 & 0,000 & 0,000 & 0,000 \\
\hline
\end{tabular}


rated neural network for selected input data scenarios, are presented in Table 10.

The data presented in Table 10 confirms a good agreement and a correct tendency of the calculations obtained from the elaborated network, in reference to the experimental test results for the set values of input parameters. The differences are at the level of $10 \%$, which is confirmed by the error set to evaluate the network. For example, for the input values presented in column 6 (number of forgings $=4000$, temperature $=1100$, deformation time $=0,083$, total time $=0,63$, pressure $=210$, lubrication $=1$, shape $=\mathrm{A}$, nitrification $=$ no, path of friction $=$ high), the network demonstrated wear at the level of $-0,0182$ $\mathrm{mm}$, that is very close to 0 , which is confirmed by the experimental tests. According to the network, the wear mechanisms for this input scenario are: thermo-mechanical fatigue $(z-\mathrm{cm})$ at the level of 0,403 , abrasive wear $(z-s)=0,295$ and plastic strain $(o-p)=0,300$. The participation of the mechanical fatigue mechanism $(\mathrm{z}-\mathrm{m})$ was determined by the network to be at the level of 0 . The experimental data in this case confirms the correctness of the results provided by the network. Precisely, these three mechanisms, with the participation of 0,33 each, were pointed to in the experimental tests. Fig. 8 illustrates an interface system developed which allowed for testing of the model.

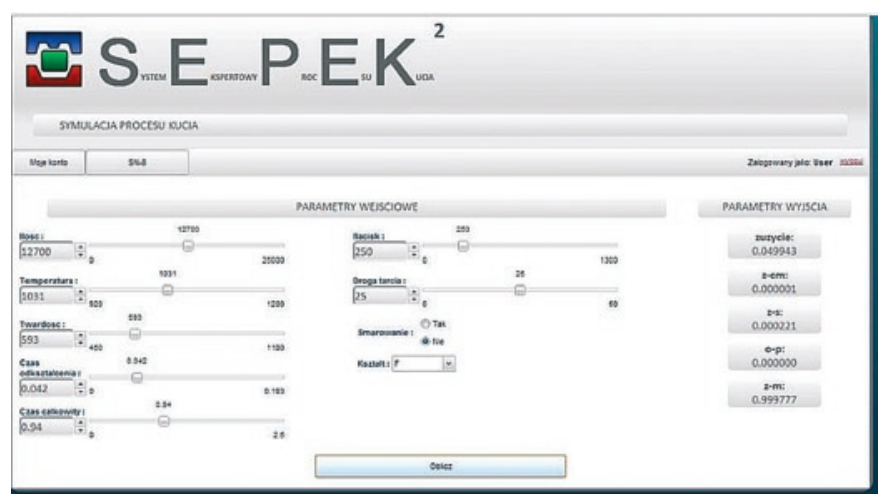

Fig. 8. Presentation of calculations by means of SEPEK interface

The developed interface is very user-friendly, as it allows for an intuitive and efficient determination of the values of the input variables (by way of shifting the slide or directly entering the data). The determination of any interesting values of input variables (number of forgings, charge temperature, hardness, deformation time and total time, pressures, path of friction, lubrication and the representative elementary tool shape), automatically generates a report on the output parameters. Preliminary tests of its use by employees working in selected die forges (i. a.: Kuźnia Jawor, Kuźnia Polska) showed a high ease into use and high functionality and practical usability.

\subsection{Global interesting results}

After successfully verifying the actions a decision support system authors conducted a a global analysis using ANN. Fig. 9a shows an example of the results of the percentage share the main mechanisms of destruction and loss of geometric material for "common conditions" prevailing in the industrial processes of forging, in the case of tools with lubrication. In contrast, in Fig. $9 \mathrm{~b}$ results for forging proc- esses, that do not use cooling and lubricant. Table 11 shows the most important parameters for the two variants of working tools: a) with lubrication and cooling, and b) without lubrication and cooling.

The results indicate that in the hot forging process for the heated tool (nitriding) and cooled, the dominant, destructive mechanism (for average number of forgings of about 15,000) is a thermo-mechanical fatigue, rather than abrasive wear. These results indicate a slightly different interpretation accepted in literature for the common view of the fact, that statistically $70 \%$ of the forging dies is withdrawn from production due to the loss dimensions - due to abrasive wear and plastic deformation, $25 \%$ - as a consequence of fatigue cracks and only $5 \%$ for other reasons (non-compliance with the technology, construction and material defects, thermal and thermo-chemical treatment defects, etc.). For a case when the tools are not lubricated and cooled percentage of the abrasive wear is dominant, increases also the share of plastic deformation. Conducted research and analyzes for other values characterizing parameters of the tools (pressure, contact times and the deformation temperature of the initial billet, etc.) confirm the relationship shown the dominance of thermal-mechanical fatigue in relation to "easily measurable" abrasive wear. In contrast, it was also observed that in case the tools are lubricated, but do not have the protective layer in the form of "nitriding" thermo-mechanical fatigue is also a parent, wherein, with the number of forging (the average number of about 7000-8000 forgings), much faster, the predominant destructive mechanism is abrasive wear.

The results presented in the diagrams were obtained based on the experimental data (450 records of knowledge were elaborated), which were used to construct a decision support system based on ASN for the analysis and prediction of forging tool durability. On this basis, the system generated the results for two different sets tool operation conditions (for exemplary work conditions data, shown in Table 11).

In the case of diagram b), Fig. 9, the collection of experimental data (vectors of knowledge) also included the values of material growth for a small number of forgings, which, as confirmed by the studies, was the result of adhesion of the forging and tool material, hence the positive values.
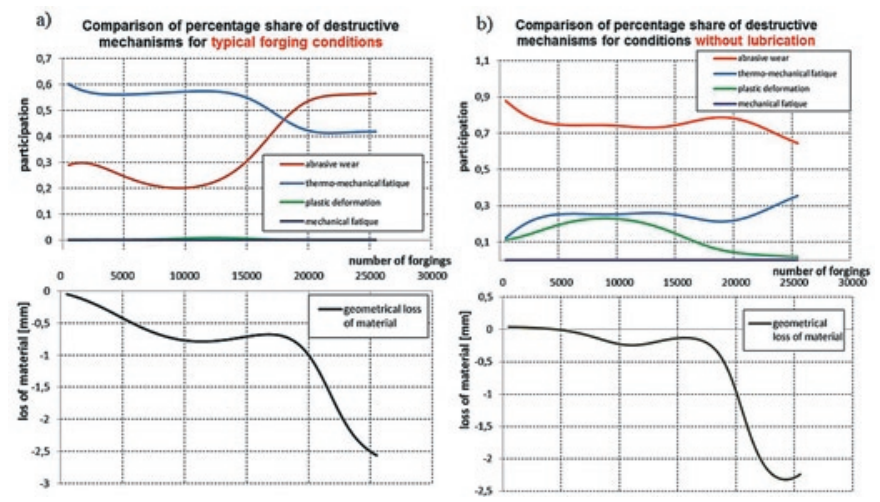

Fig. 9. Comparison of the percentage share results of the main mechanisms of destruction and loss of material with growing number of forgings: a) typical conditions - tools heated, lubricated and cooled, b) "nonstandard conditions" prevailing in the industrial processes of forging - without lubrication

Table 11. The most important parameters of the forging tools: a) the typical conditions prevailing in the forging process for tools with lubrication, b) tools without lubrication and cooling

\begin{tabular}{|c|c|c|c|c|c|c||}
\hline Work conditions & $\begin{array}{c}\text { Tem- } \\
\text { perature of } \\
\text { billet } \\
{\left[{ }^{\circ} \mathbf{C}\right]}\end{array}$ & $\begin{array}{c}\text { Normal stress of Sur- } \\
\text { face tool detemined by } \\
\text { FEM [MPa] }\end{array}$ & $\begin{array}{c}\text { Forming time } \\
\text { (forging) } \\
\text { [s] }\end{array}$ & $\begin{array}{c}\text { Total contact time } \\
\text { deformated material } \\
\text { with tool [s] }\end{array}$ & Nitriding & $\begin{array}{c}\text { Lubrication } \\
\text { and cooling }\end{array}$ \\
\hline With lubrication & 1100 & 650 & 0,097 & 0,717 & yes & yes \\
\hline Without lubrication & 1100 & 650 & 0,097 & 0,717 & no \\
\hline
\end{tabular}



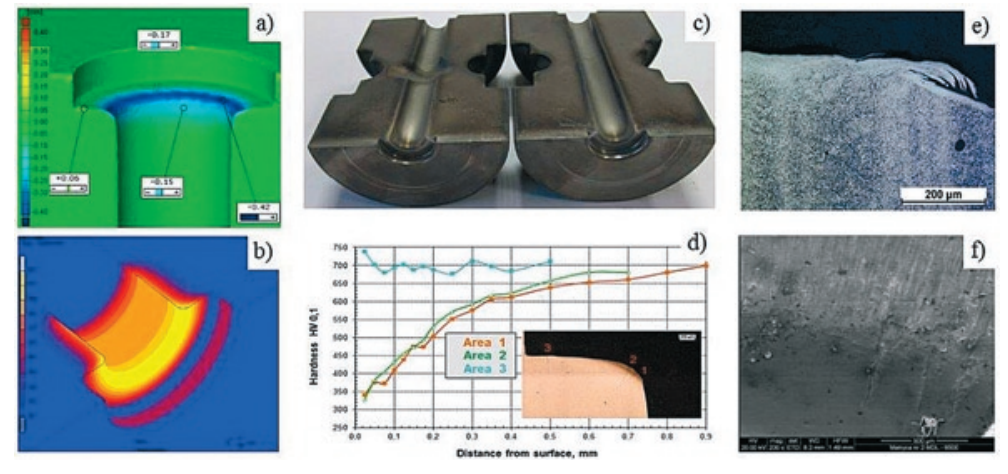

Fig. 10. Analysis of non-lubricated and non-cooled tools: a) results of scanning for the collar area, b) temperature distribution in the most worn area, obtained from $M E S, c)$ view of the dies used to forge a construction catch in the first operation, d) microhardness measurement results, e) plastic deformations in the analyzed area-metallographic microscope, e) traces of abrasive wear-scanning microscope

The local extremes in both diagrams with the number of over 15 thousand forgings, are caused by the fact that, in the experimental studies, different tools from the same processes were selected (after different numbers of produced forgings), and so, the obtained results e.g. of the measurement of material loss for the tool after 12 thousand forgings and another after 15 thousand, can vary slightly.

It should be noted that these results, obtained with the use of the elaborated system, provide error at the level of up to $10 \%$. Also, the experimental data did not include (cover) all the areas, i.e. from 0 to 25 thousand forgings.

What is more, it was observed that, due to the working conditions of the tools with similar numbers of forgings (about 17000, for both sets of tool working conditions), a rapid increase of material loss occurred. The macro- and micro-studies showed that larger parts of material were detached, e.g. of the nitrided layer from different areas or the oxidized and cracking network of thermo-mechanical fatigue, which intensified the mechanism of abrasive wear, as they worked as hard particles, abrading and taking away other parts of the tool material. It is interesting to notice that, in the case of lubricated and cooled tools, from as few as 20 thousand forgings up, we observe an increase of the participation of thermal fatigue in respect of abrasive wear. This case is slightly different than the one of non-cooled and non-lubricated tools, for which, with the same number of forgings, a drop of abrasive wear was observed, with a simultaneous increase of thermo-mechanical fatigue.

The studies of the methods of evaluation and analysis of forging tool durability, presented in works $[8,9,11]$, have shown that: most of the degradation mechanisms in the die forging processes performed at elevated temperatures cause and reveal themselves in the form material loss or shape change. The wear intensity changes with the change of the process parameters, which is determined mainly by the contact time, pressure values, temperature changes and tribological conditions. That is why it has been commonly assumed that it is abrasive wear which is the dominating degradation mechanism, whereas the second dominating mechanism is plastic deformation. And so, very often, in many elaborations, most of the degradation mechanisms are modelled by means of the Archard abrasive wear model. As it has been demonstrated by the results $[6,8]$ of the presented microstructural tests, the results of surface scanning (Fig 10-11) and implemented to database in the decision support system and the results obtained from the expert system, the most frequently occurring as well as dominating mechanism is thermo-mechanical fatigue, which additionally accelerates the other degradation mechanisms. On this basis, it can draw, that in hot die forging processes, in the case when the tools, in a particular operation or in the whole process, are not lubricated and cooled, it can be assumed that abrasive wear is the actual dominant degradation mech- anism, and thermo-mechanical fatigue plays a secondary role. In such cases, the percentage of plastic deformations increases as well, as a result of the effect of temperature, which causes local tempering of the tool material and lowering of durability. Fig. 10 shows images of exemplary tools, in the analyzed processes, for which the descried situation takes place.

In contrast, for forging tools working under typical conditions, such as hot and semi-hot die forging processes, which are lubricated and cooled, thermo-mechanical fatigue is mostly the dominant mechanism. As a result of periodical temperature changes, during the forging process, we observe an alternating expansion and 'shrinkage' of the surface layer of the die, which, in consequence, leads to the formation of a thermal crack network. The latter, as a result of periodical mechanical loads, causes an increase in the stress concentration and expands by forming a primary and, in time also, secondary crack network. The spalling of the thermo-mechanical fatigue network causes a further expansion of cracks and intensifies the abrasive wear. The crack expansion is also favoured by the presence of scale, which, by filling the crack, can work as a 'wedge'. Under such process conidtions, plastic deformations basically do not occur. Fig. 11 presents a comparison of the state of the tools (die inserts) after performance, used in the industrial process of forging a front wheel, for the first operation (no lubrication or cooling) as well as for the second operation (the tools are lubricated and cooled).
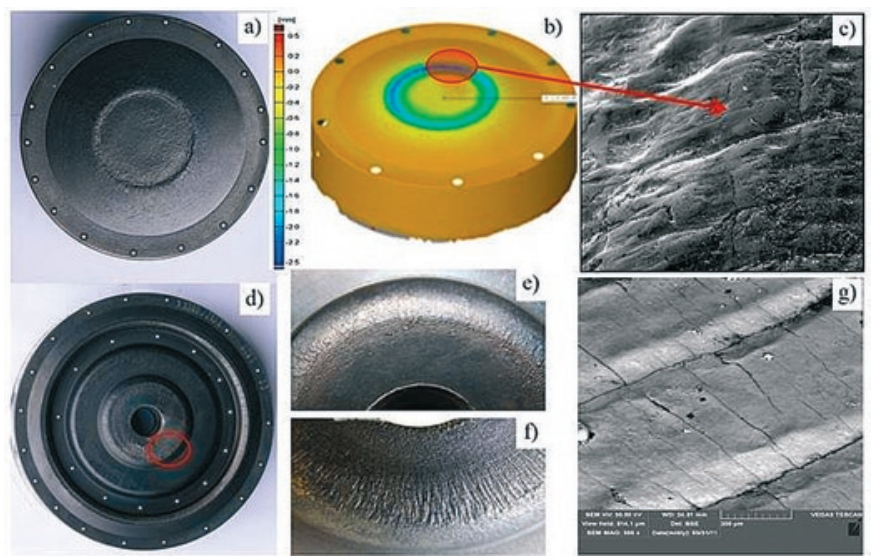

Fig. 11. Comparative analysis of unlubricated tools with lubricated and cooled tools, used in the same forging process: a) lower die insert after 9000 forgings, b) tool scanning results, c) SEM image from the selected die area-traces of plastic deformation, abrasive wear and oxidation, d) lower die insert after 1850 forgings, e) image of the insert front from the selected area after 550 forgings, $f$ ) after 4300 forgings, $g$ ) SEM image of the insert front from the marked area in Fig. 11d-visible primary network of thermal fatigue, traces of grooves formed as a result of abrasive wear by hard particles

Fig. 11 shows the results of the state of tools (die inserts) after their exploitation, used in the manufacturing process of wheel forging process for different working conditions confirmed the complexity of the occurrence of many destructive mechanisms, both in different regions of the tool, as well as the change and the progression of wear with increasing the number of forgings.

The presented comparison illustrates very well the complexity and variety of the mechanisms occurring in the case of forging tools, which confirms my conviction even more that the analysis of durability is still an existing challenge.

\section{Summary}

The work involves the use of artificial neural networks in a decision support system in durability prediction of forging tools used in the hot die industrial forging processes. 
Forging tools (dies and punches) designed by engineers and technologists used in the die industrial forging process wear usually much earlier than it was planned. The durability of forging tools depends primarily on: the conditions under which extends the forging process, the design and construction of tools, their proper heat treatment, appropriate for the tool material, the shape initial billet and preform and also a lubrication and cooling systems, etc. Therefore, it is advisable to systems development systems which provide the best choice of tools working conditions in order to increase its life. Developed a decision support system is an excellent IT, which could support and supplement work of process engineer in the selection of the optimal working conditions of forging tools. In the manuscript presented a prototype version of such a system.

Presented in the article the system has been developed based on the experimental data obtained for selected representative industrial die forging processes, which include most of the processes implemented in die forges. As the formal tool representing the knowledge in the system, an artificial neural network was used. The set of data applied for network training contained 450 training cases coming from the performed experimental research as well as computer simulations. The results show that, by parameterizing the crucial factors of the forging process, it is possible to develop an evaluation system of the percentage of the typical failure mechanisms (thermo-mechanical fatigue, mechanical wear, abrasive wear and plastic strain) and to calculate the value of the geometrical defect of the tools.

Predicting the degree of wear/failure of the die and the type of mechanisms responsible for this, with the assumed parameters of its work, is a very complex process, difficult to design. The collected source data and the neural network elaborated on its basis make the assessment error at the level of $10 \%$, which, considering the complication of the problem, is a satisfactory result. The level of the global error with which the network model performs the calculations is at the level of $10 \%$ (testing error $=0,09$ ) and it is comparable with the value of the error determined for the first version of the SEPEK system, formalized by means of fuzzy logic $(0-10 \%$ for the percentages of wear mechanisms; $0-15 \%$ for the parameter of the wear degree). Considering the large differences in the wear of the particular tools and the fact that pointing to the mechanism determining the wear cannot always be clear, even in the case when it is performed by an experienced expert, it can be assumed that the elaborated system provides results with an acceptable error. One should also emphasize the fact that the results obtained by the system have been verified and positively evaluated by experts.

Carried out thanks to decision support system-based on ANN global analysis and other durability testing showed that fatigue thermomechanical destruction due to oxidation, very often occur together with the mechanism of wear, creating a synergy effect, causing the acceleration, the most visible and "easily measurable" process abrasive wear. So, as clearly mentioned in the available literature rightly given that as many as $70 \%$ of all withdrawn of forging tools from further exploitation is the result of wear. But not informed by the fact that a significant part of this share is caused by the strengthening of the destructive mechanism mainly due to thermo-mechanical fatigue. The synergy between these mechanisms results in detachment of non-cyclic large particles for tool with a primary or secondary grid of cracks and detachment of the cyclic much smaller particles - scale in the form of hard oxides. All of these particles as a result of thermal fatigue and oxidation work as a kind of abrasive greatly intensifying the destruction process as a result of wear (abrasive wear). This in turn leads to a sometimes very large changes in geometry tools which translate directly to the forging, which from the point of view quality and functionality of such a product is not permitted.

The further work aiming at perfecting the model will be connected with the process of optimizing the network and introducing a larger amount of training data obtained from the consecutive experimental data.

The results obtained and presented in the manuscript are distinctly application character, because based on the these analysis concerning of destructive mechanisms can be used appropriate methods or preventive measures that will allow to increase the durability of forging tools. The recipients of this type of decision support systems are, as revealed preliminary research especially technologists and engineers working in the die forges.

\section{Acknowledgements}

This study was found by National Centre for Research and Development, Poland (NCBiR); grant no. POIG.01.03.01-02-063/12.

\section{References}

1 Altan T. Cold and hot forging fundamentals and application. ASM Internation, Ohio 2005.

2. Azari A, Poursina, M. i Poursina, D. Radial forging force prediction through MR, ANN and ANFIS models. Neural Computing \& Applications 2014; 25(3-4): 849-858, https://doi.org/10.1007/s00521-014-1562-8.

3. Gangopadhyay T, Kumar D, Pratihar I. Expert system to predict forging load and axial stress. Appl. Soft. Comput. 2014; 11(1): 744-753, https://doi.org/10.1016/j.asoc.2009.12.036.

4. Gronostajski Z, Hawryluk M, Jaśkiewicz K, Niechajowicz A, Polak S, Walczak S, Woźniak A. Application of physical and mathematical modelling to analysis of different forging processes of constant velocity joint body. Computer Methods in Materials Sciences 2007; 7(2): 231-236.

5. Gronostajski Z, Hawryluk M, Kaszuba M, Marciniak M, Niechajowicz A, Polak S, et al. The expert system supporting the assessment of the durability of forging tools. The International Journal of Advanced Manufacturing Technology 2015; 82(9): 1973-1991.

6. Gronostajski Z, Hawryluk M, Kaszuba M, Ziemba J. Application of a measuring arm with an integrated laser scanner in the analysis of the shape changes of forging instrumentation during production. Eksploatacja i Niezawodnosc - Maintenance and Reliability 2016; 18 (2): $194-$ 200, https://doi.org/10.17531/ein.2016.2.6

7. Gronostajski Z, Hawryluk M. The main aspects of precision forging. Archives of Civil and Mechanical Engineering 2008; 8(2): 39-57, https://doi.org/10.1016/S1644-9665(12)60192-7.

8. Gronostajski Z, Kaszuba M, Hawryluk M, Zwierzchowski M. A review of the degradation mechanisms of the hot forging tools. Archives of Civil and Mechanical Engineering 20014; 14: 528-539, https://doi.org/10.1016/j.acme.2014.07.002.

9. Gronostajski Z, Kaszuba M, Polak S, Zwierzchowski M, Niechajowicz A, Hawryluk M. The failure mechanisms of hot forging dies. Materials Science and Engineering. A, Structural Materials: Properties, Microstructure and Processing 2016; 657: 147-160, https://doi.org/10.1016/j. msea.2016.01.030.

10. Hawryluk M, Kaszuba M, Gronostajski Z, Sadowski P. Systems of supervision and analysis of industrial forging processes. Eksploatacja i Niezawodnosc - Maintenance and Reliability 2016; 18 (3): 315-324, https://doi.org/10.17531/ein..2016.3.1 
11. Hawryluk M. Metody analizy oraz zwiększania trwałości narzędzi kuźniczych stosowanych w procesach kucia matrycowego na gorąco. Monograficzna seria wydawnicza Problemy Eksploatacji i Budowy Maszyn, ISBN 978-83-7789-410-1, Wyd. Naukowe ITE - PIB, Radom 2016.

12. Hawryluk, M. Review of selected methods of increasing the life of forging tools in hot die forging processes. Archives of Civil and Mechanical Engineering 2016;16: 845-866, http://dx.DOI:0.1016/j.acme.2016.06.001.

13. Heinemeyer D. Gensekschäden und Einflussgrössen der Standmenge. Industrieanzeiger 1978; 100 (73).

14. Katayama T, Akamatsu M, Tanaka Y. Construction of PC based expert system for cold forging process design. J Mater. Process. Technol. 2004; 155-156: 1583-1589, https://doi.org/10.1016/j.jmatprotec.2004.04.256.

15. Kocańda S, Kocańda A. Niskocyklowa wytrzymałość zmęczeniowa metali. PWN, Warszawa 1989.

16. Lange K, Cser L, Geiger M, Kals J,A.G. Tool Life and Tool Quality in Bulk Metal Forming. Proceedings of the Institution of Mechanical Engineers, Part B: Journal of Engineering Manufacture November 1993; 207 : 223-239, https://doi.org/10.1243/PIME_ PROC_1993_207_085_02.

17. Lapovok R, Smirnov S, Shveykin V. Damage mechanics for the fracture prediction of metal forming tools. International Journal of Fracture 2000; 103(2): 111-126, https://doi.org/10.1023/A:1007593623392.

18. Li M, Liu,X, Xiong A. Prediction of the mechanical properties of forged TC11 titanium alloy by ANN. Journal Of Materials Processing Technology 2012; 121(1): 1-4, https://doi.org/10.1016/S0924-0136(01)01006-8.

19. Mazurkiewicz D. Maintenance of belt conveyors using an expert system based on fuzzy logic. Archives of Civil and Mechanical Engineering 2015;15(2) : 412-418, https://doi.org/10.1016/j.acme.2014.12.009.

20. Osowski, S. Sieci neuronowe w ujęciu algorytmicznym. WNT. Warszawa 1996.

21. Rauch L, Chmura A, Gronostajski Z, Pietrzyk M, Zwierzchowski M. Cellular automata model for prediction of crack initiation and propagation in hot forging tools. Archives of Civil and Mechanical Engineering 2016; 16(3) : 437-447, https://doi.org/10.1016/j.acme.2016.02.008.

22. Rosenblatt F. The perceptron: A probabilistic model for information storage and organization in the brain. Psychological Review 1958; 65(6): 386- 408, https://doi.org/10.1037/h0042519.

23. Smolik J. Rola warstw hybrydowych typu warstwa azotowana/ powłoka PVD w procesie zwiększania trwałości matryc kuźniczych. WITE. Radom 2007.

24. Subba Rao A.V, Pratihar D,K. Fuzzy logic-based expert system to predict the results of finite element analysis. Knowl-Based Syst. 2007; 20: 37-50, https://doi.org/10.1016/j.knosys.2006.07.004.

25. Sun Y, Hu L. Modelling optimisation of hot processing parameters of Ti-6Al-4V alloy using artificial neural network and genetic algorithm. Materials Research Innovations 2014; 18: 1052-1056, https://doi.org/10.1179/1432891714Z.000000000856.

26. Tadeusiewicz R, Gąciarz T, Borowik B, Leper B. Odkrywanie właściwości sieci neuronowych, przy użyciu programów w języku C \#. Polska Akademia Umiejętności, Międzywydziałowa Komisja Nauk Technicznych, Kraków 2007.

27. Tadeusiewicz R. Neural networks in mining sciences - general overview and some representative examples. Arch. Min. Scien. 2015; 60 (4): 971-984, https://doi.org/10.1515/amsc-2015-0064.

28. Tadeusiewicz R. Neural networks.PWN. Warszawa 1993.

29. Tompos A, Margitfalvi JL, Tfirst E, He'berger K. Predictive performance of 'highly complex' artificial neural networks. Appl Catal Gen. 2007; 324: 90-93, https://doi.org/10.1016/j.apcata.2007.02.052.

\author{
Marek HAWRYLUK \\ Department of Metal Forming and Metrology \\ Faculty of Mechanical Engineering \\ Wrocław University of Science and Technology \\ Wybrzeże Wyspiańskiego 25, 50-370 Wroclaw, Poland
}

\section{Barbara MRZYGŁÓD}

Department of Applied Computer Science and Modelling Faculty of Metals Engineering and Industrial Computer Science AGH - University of Science and Technology

Al. Mickiewicza 30, 30-059 Cracow, Poland

E-mails: marek.hawryluk@pwr.edu.pl,mrzyglod@agh.edu.pl 